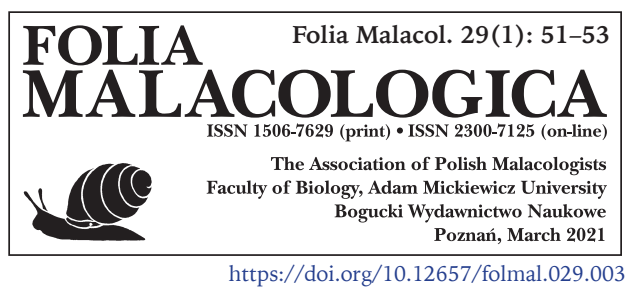

SHORT COMMUNICATION

\title{
FIRST RECORD OF EOBANIA VERMICULATA \\ (O. F. MÜLLER, 1774) \\ (GASTROPODA: EUPULMONATA: HELICIDAE) IN ROMANIA
}

\author{
STELIAN GRIGORE
}

\begin{abstract}
Museum of Human Evolution and Technology in Paleolithic, Princely Court National Museum Targoviste, Romania (e-mail: stelian.grigore@gmail.com); (1) https://orcid.org/0000-0002-9384-3634

ABSTRACT: Eobania vermiculata (O. F. Müller) is recorded for the first time in Romania. Other Mediterranean and Balkan species have entered the south of Romania - Dobrogea, or will do so in the near future. We expect the rest of Romania to be invaded, because the Danube is not an insurmountable barrier for some of these species.
\end{abstract}

KEY WORDS: Eobania vermiculata; alien species; land snail; anthropochory

A northward expansion of some terrestrial gastropod species has been observed for the last two decades; the spread has been accelerated by the intensification of trade, tourism development and cross-border freight transport. Among the regions of Romania, Dobrogea has the most favourable condi-

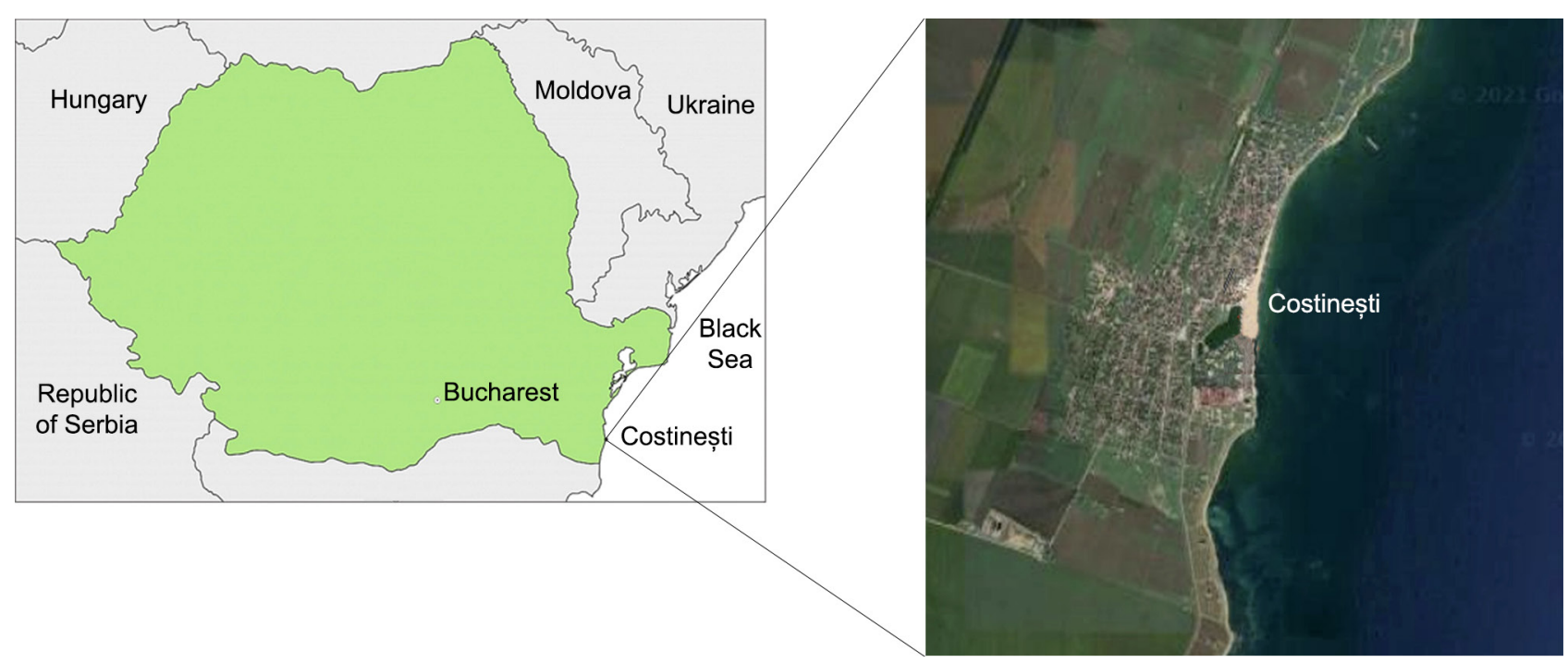

tions for the invasion of Balkan and Mediterranean species. The climate and calcareous substrate of the coastal area in south-eastern Dobrogea favour acclimatisation of the new arrivals.

As early as four decades ago, Alexandru V. Grossu anticipated the occurrence of this phenomenon in the

Fig. 1. Map of Romania with the locality in Costinești 


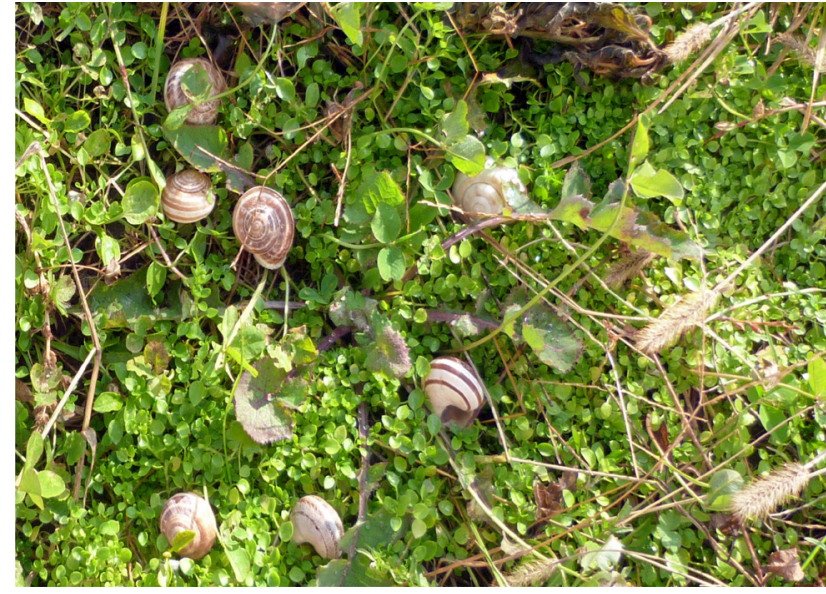

Fig. 2. Mature individuals of Eobania vermiculata in Costinești

near future (GROssu 1983). In the last two decades, there has been an expansion of the Mediterranean species both in the east and in the northwest of their original range (MIENIS 2002, UESHIMA et al. 2004, AL-KHAYAT 2010, PELTANOVÁ et al. 2012, AL-KHAFAJI et al. 2016, RONSMANS \& VAN DEN NEUCKER 2016, PÁLL-GERGELY et al. 2020). The purpose of this short communication is to confirm with certainty the first record of Eobania vermiculata (O. F. Müller, 1774) in the Romanian mollusc fauna.

The terrestrial gastropod fauna of the Dobrogea region has been studied since the 19th century, being the subject of numerous works until the last decade of the 20th century (MONTANDON 1887, LICHERDOPOL 1900, GROSSU 1972, ZEISSLER 1983, NEGREA 1994). During the period 1990-2020, the region was monitored annually in April-May and September-October. On April 30th 2015, on the seafront of Costinești Town (Fig. 1), 22 mature specimens of E. vermiculata were found in the Flutist Girl Statue Park $\left(43^{\circ} 56.62^{\prime} \mathrm{N}, 28^{\circ} 38.29^{\prime} \mathrm{E}\right)$.

The habitat in which the snails live is located on a terrace, 6 metres above sea level, right on the seafront, 20 metres from the sea shore. The bedrock is composed of Sarmatian limestones, covered by a loess deposit and consolidated sands and clays. The habitat is a wasteland, bordered by a hedge of Ligustrum vulgare, with Elaeagnus angustifolia and an association

\section{REFERENCES}

Al-Khafaji K. S., ABUd-SAHAB A. M., AZIZ N. M. 2016. First records of terrestrial snail Eobania vermiculata (Gastropoda: Helicidae) from Basrah areas, IRAQ. Arthropods 5: 125-129.

AL-KHAYAT J. A. 2010. First record of five terrestrial snails in the State of QATAR. Turkish Journal of Zoology 34: 539-545.

BANDOC G., PRĂVĂLIE R. 2015. Climatic water balance dynamics over the last five decades in Romania most arid

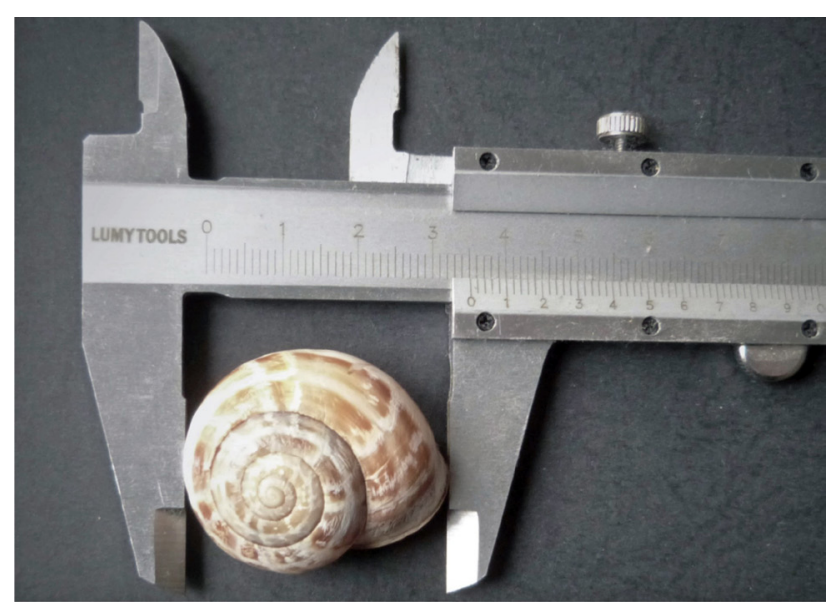

Fig. 3. The largest shell of Eobania vermiculata from Costinești

of perennials (Cichorium intybus, Convolvulus arvensis, Echium vulgare, Elymus repens, Crupina vulgaris, Phleum pratense, Malva pusilla, Teucrium polium, Juncus maritimus, Taraxacum officinale, Plantago major). More than 100 specimens were collected in the period 20152019; their diameter was 25-35 $\mathrm{mm}$ and height 16 $23 \mathrm{~mm}$ (Fig. 2).

Taxonomic identification and morphometric measurements were done at the Malacological Documentation and Research Center (Neamt County, Romania), using classical methods (HESSE 1913, NEUBERT 1998) as well as recent ones (RAĐA et al. 2012, WELTER-SCHULTES 2012, BOUAZIZ-YAHIATENE et al. 2017, HOLYOAK et al. 2020). Comparative material from Greece, Turkey, Bulgaria and Croatia, was used for verification.

One of the shells had the largest hitherto recorded diameter, D $35.2 \mathrm{~mm}$ (Fig. 3). It exceeded the one recorded from Gavdos Island (Greece), D $33.5 \mathrm{~mm}$ (LAZARIDOU-DIMITRIADOU \& KATTOULAS 1981).

The Circum-Pontic climate has undergone significant changes in recent decades, such as the increase of the average annual temperature in the Dobrogea region (BANDOC \& PRĂVĂLIE 2015). The population of $E$. vermiculata from Costinesti seems to be fully adapted to the environment and is developing; it is currently subject to an ecological study which will be published this year.

region, Dobrogea. Journal of Geographical Sciences 25: 1307-1327.

https://doi.org/10.1007/s11442-015-1236-1

Bouaziz-Yahiatene H., Pfarer B., Medjdoub-BensaAd F., NEUBERT E. 2017. Revision of Massylaea Mollendorff 1898. (Stylomatophora, Helicidae). ZooKeys 694: 109-133. https://doi.org/10.3897/zookeys.694.15001

Grossu A. V. 1972. Deroceras thersites, o nouă specie balcanică în fauna României. Studii și Cercetări Biologice, 
Seria Zoologie, Editura Academiei R.S.R. București 25: 3-5.

Grossu A. V. 1983. Gastropoda Romaniae, vol. 4. Editura Litera, București.

Hesse P. 1913. Zur Kenntis der Molluskenfauna von Ostrumelien. II. Nachrichtsblatt der Deutschen Malakozoologischen Gesellschaft, Frankfurt am Main 45: 1-16.

Holyoak D. T., Holyoak G. A., GOMez Moliner B. J., ChueCA L. J. 2020. Phylogeny, species-limits and taxonomic revision of Otalini (Helicidae) from north-west Africa. Journal of Conchology 43: 551-611.

LAZARIDOU-DimitriadoU M., KATTOUlas M. 1981. Contribution a l'etude de la biologie et de la croissance des escargots commercialises en Grece: Eobania vermiculata et Helix aspersa. Haliotis 11: 129-137.

LICHERDOPOL I. P. 1900. Excursiuni în Dobrogea: Lista moluscelor dobrogene. Editura Carol Gobl, București, pp. 122-126.

MIENIS H. K. 2002. Eobania vermiculata in Iran. Triton 6: 27.

MONTANDON A. L. 1887. Excursions en Dobroudja. Bulletin de la Société d'Études Scientifiques d'Angers: 31-64.

NEGREA A. 1994. Contribuții la cunoașterea Gasteropodelor pulmonate din Dobrogea (România). Studii și Cercetări de Biologie, Seria Biologie Animală, Editura Academiei Române 461: 3-14.

NeuberT E. 1998. Annotated checklist of the terrestrial and freshwater molluscs of the Arabian Peninsula with descriptions of new species. Fauna of Arabia 17: 333-461.

PÁll-Gergely B., FehÉR Z., ČEJKA T. 2020. New records of the Mediterranean land snail Massylaea vermiculata
(O. F. Müller, 1774) in Hungary and Slovakia. Folia Malacologica 28: 337-341.

https://doi.org/10.12657/folmal.028.021

PElTANOVÁ A., PETRUSEK A., KMENT P., JUŘIČKOVÁ L. 2012. A fast snail's pace: colonization of Central Europe by Mediterranean gastropods. Biological Invasions 14: 759-764. https://doi.org/10.1007/s10530-011-0121-9

RAĐA B., RAĐA T., PUIZINA J., ŠAMANIĆ I., SANTIC M. 2012. Shell characteristics of land snail Eobania vermiculata (O. F. Müller, 1774) (Helicidae) from Croatia. American Malacological Bulletin 30: 299-307. https://doi.org/10.4003/006.030.0209

RONSMANS J., VAN DEN NEUCKER T. 2016. A persistent population of the chocolate-band snail Eobania vermiculata (Gastropoda: Helicidae) in Belgium. Belgian Journal of Zoology 146: 66-68. https://doi.org/10.26496/bjz.2016.41

UESHIMA R., OKAMOTO M., SAITO Y. 2004. Eobania vermiculata, a land snail newly introduced in Japan. Chirobotan 35: 71-74.

WELTER-SCHULTES F. W. 2012. European non-marine molluscs, a guide for species identification. Planet Poster Editions, Göttingen.

ZEISSLER H. 1983. Schnecken im Sogennanten Wald von der Mangalia-Neptun sowie und Waldschnecken aus der südlichen Dobrudscha (Rumänien) (Gastropoda). Malakologische Abhandlungen des Staatliches Museum für Tierkunde Dresden 9: 63-68.

Received: February 15th, 2021

Revised: February 23rd, 2021

Accepted: February 28th, 2021

Published on-line: March 19th, 2021 